\title{
Effects of piperine in experimental intestinal ischemia reperfusion model in rats
}

\author{
Hızır Yakup Akyıldız, M.D., Adem Karabacak, M.D., Muhammet Akyüz, M.D., \\ Erdoğan Sözüer, M.D., Alper Akcan, M.D.
}

Department of General Surgery, Erciyes University Faculty of Medicine, Kayseri

\begin{abstract}
BACKGROUND: Piperine is a spice principle, and its protective role against oxidative damage and lipid peroxidation has been reported. In this study, we aimed to investigate the effects of piperine in the prevention of ischemia-reperfusion injury to the small intestine.
\end{abstract}

METHODS: Rats were allocated to three groups of 8 rats each. Rats in the sham group underwent laparotomy and observation only. Animals in the control and study groups underwent 45 minutes ischemia followed by 60 minutes reperfusion. In the study group, 10 $\mathrm{mg} / \mathrm{kg}$ piperine was administered intraperitoneally just before the reperfusion procedure. Blood samples were obtained for measurement of lactate levels, and resection of the terminal ileum was performed to evaluate the histopathologic specimens and tissue malondialdehyde, superoxide dismutase, and glutathione activities. All results were expressed as mean \pm SD. Comparisons between groups were made by using the one way analysis of variance (ANOVA).

RESULTS: Lactate and malondialdehyde levels were significantly higher in the control group than the study and sham groups ( $<<0.00 \mathrm{I})$. In the study group, superoxide dismutase, and glutathione activities were significantly higher than in the control group ( $p<0.00 \mathrm{I}$ ). The sham group had the highest activities. Histopathologic examination showed disruption of villous pattern and lamina propria in the control group.

CONCLUSION: Intraperitoneal administration of $10 \mathrm{mg} / \mathrm{kg}$ piperine just before the reperfusion may reduce ischemia-reperfusion injury to the small intestine.

Key words: Ischemia; piperine; reperfusion; small intestine.

\section{INTRODUCTION}

Intestinal ischemia-reperfusion is a common clinical event associated with both clinical and experimental distant organ injury. Arterial ischemia initiates alterations in tissues by blocking the oxygen supply, thus impeding aerobic energetic metabolism. During the ischemia process, there is an accumulation of metabolites, which, directly or through mediators, can cause cellular injury. ${ }^{[1,2]}$ Depending on the time and

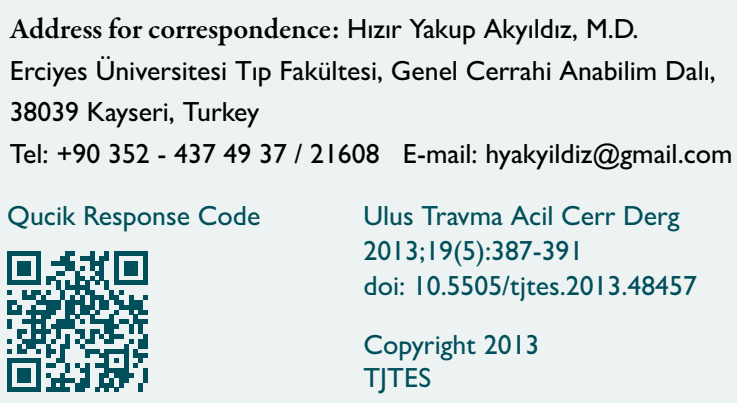

intensity of the ischemia, when oxygen is reintroduced to the tissues, tissue injury can be further exacerbated (oxygen paradox). ${ }^{[3]}$ Reperfusion leads to an aggravation of ischemic cell damage, especially reactive oxygen species (ROS) derived from activated Kupffer cells and neutrophils. ${ }^{[4]}$ ROS and reactive metabolic intermediates generated from various oxidative factors are known to have an important role in cell damage and in the progression of ischemia-reperfusion injury $(\mathrm{IRI}) .{ }^{\left[{ }^{[}\right]}$Despite intensive researches that have aimed to investigate the pathogenesis and find a way to prevent or decrease the additional deleterious effect of IRI, the underlying mechanisms remain to be elucidated.

There are many reports indicating that various spice principles form an important group as antioxidants. Piperine is a pungent alkaloid present in black and white pepper (Piper nigrum), long used as a spice and preservative. ${ }^{[6]}$ Piperine has been shown to alter both the bioavailability ${ }^{[7]}$ and biotransformation $^{[8,9]}$ of xenobiotics, and to alter lipid peroxidation and availability of glutathione in the $\operatorname{liver}^{[10]}$ and intestine. ${ }^{[1]}$ Piperine has also been demonstrated in in vitro experiments 
to protect against oxidative damage by inhibiting or quenching free radicals and ROS and inhibiting lipid peroxidation. ${ }^{[12]}$ We report here the results of an experimental study to evaluate whether intraperitoneal administration of piperine could be an effective strategy to reduce intestinal IRI.

\section{MATERIALS AND METHODS}

This study was performed at Erciyes University Experimental Research Center. Twenty-four male Wistar-Albino rats weighing 250 to $300 \mathrm{~g}$ were used for this study. Pre- and postoperatively, the animals were maintained under controlled conditions of temperature $\left(21-24^{\circ} \mathrm{C}\right)$, humidity $(40 \%-$ $60 \%$ ), and light (12-hour light/dark cycle) and fed ad libitum on rat cubes and tap water. Our institutional ethical committee approved the experimental procedures of this study. The animals were divided randomly into three groups containing 8 rats each as follows: group I (sham), animals were sacrificed at the end of 105 minutes (min) observation after laparotomy; group 2 (control), operative procedure without further treatment; and group 3 (study), operative procedure with intraperitoneal piperine administration $(10 \mathrm{mg} / \mathrm{kg}){ }^{[6]} \mathrm{ln}$ testinal ischemia was induced by microvascular clip occlusion of the superior mesenteric artery (SMA) for 45 min. Reperfusion was performed for 60 min after SMA clip removal. ${ }^{[13]}$ In the study group, intraperitoneal piperine (Sigma, P49007, 10 $\mathrm{mg} / \mathrm{kg}$ ) was administered at the end of $45 \mathrm{~min}$ ischemia just before the removal of the microvascular clip.

\section{Operative Procedures}

The rats were anesthetized using intraperitoneal ketamine hydrochloride (Ketalar; Parke Davis-EWL, İstanbul, Turkey; $20 \mathrm{mg} / \mathrm{kg}$ body weight) and xylazine (Rompun, Bayer, İstanbul, $10 \mathrm{mg} / \mathrm{kg}$ ). After the abdomen was shaved and cleansed with povidone iodine solution, a 5-6-cm midline laparotomy was performed. All procedures were performed under sterile conditions by one surgeon who was blinded to the animal allocations. In groups 2 and 3 , I ml heparinized blood for serum lactate analysis was obtained from the inferior vena cava after reperfusion, while in the sham group, it was obtained after the end of the observation period. For tissue analysis, a $3-\mathrm{cm}$ ileal segment $10 \mathrm{~cm}$ proximal to the ileocecal valve was removed, and $2 \mathrm{~cm}$ was fixed in 10\% neutral buffered formalin and embedded in paraffin for histopathological evaluation. Paraffin sections $5 \mu \mathrm{m}$ in thickness were cut and stained with hematoxylin and eosin. Assessment of ileal injury was performed by light microscopy using a scoring system devised by Chiu et al. without knowledge of the study groups. The remaining $\mathrm{I} \mathrm{cm}$ was conserved in an aluminum foil at $-80^{\circ} \mathrm{C}$ for tissue malondialdehyde (MDA), superoxide dismutase (SOD) and glutathione peroxidase (GSH) activities.

\section{Statistical Analysis}

All results were expressed as mean $\pm S D$. Comparisons of MDA, SOD and lactate between groups were made by using the one way analysis of variance (ANOVA). Post-hoc comparisons of parameters were performed using the Tukey procedure. Statistical significance was set at $p<0.05$. All analyses were performed with the Statistical Package for Scientists (SIGMASTAT) Windows version 3.50.

\section{RESULTS}

Lactate levels were $1.29 \pm 0.07 \mathrm{mmol} / \mathrm{L}$ in the sham, $3.29 \pm 0.06$ $\mathrm{mmol} / \mathrm{L}$ in the control and $1.86 \pm 0.07 \mathrm{mmol} / \mathrm{L}$ in the piperine groups. The sham group had the lowest level while the control group had the highest, and the differences were statistically significant $(p<0.00$ I for all) (Fig. Ia). Tissue MDA contents were $0.16 \pm 0.02 \mu \mathrm{M} / \mathrm{mg}$ in the sham, $0.38 \pm 0.05 \mu \mathrm{M} / \mathrm{mg}$ in the control and $0.22 \pm 0.04 \mu \mathrm{M} / \mathrm{mg}$ in the piperine groups, and the content was significantly lower in the sham group. The control group had significantly higher content than the others $(p<0.001)$ (Fig. Ib).

Tissue SOD levels were $5.13 \pm 0.57 \mathrm{U} / \mathrm{ml} / \mathrm{g}$ in the sham, $2.70 \pm 0.57 \mathrm{U} / \mathrm{ml} / \mathrm{g}$ in the control and $3.77 \pm 0.48 \mathrm{U} / \mathrm{ml} / \mathrm{g}$ in the piperine groups. The sham group had the significantly highest level while the control group had the significantly lowest level $(p<0.00$ I) (Fig. Ic). Tissue GSH levels were 89.06 \pm I I.78 $\mathrm{nmol} / \mathrm{ml} / \mathrm{g}$ in the sham, $32.89 \pm 6.55 \mathrm{nmol} / \mathrm{ml} / \mathrm{g}$ in the control and $64.16 \pm 10.45 \mathrm{nmol} / \mathrm{ml} / \mathrm{g}$ in the piperine groups. The level in the sham group was significantly higher than in the others. The control group had the significantly lowest level $(p<0.00 \mathrm{I})$ (Fig. Id).

Histopathologic examination of the specimens showed well-preserved villi and intact intestinal mucosa in the sham group. Disruption of villous pattern, increased cellularity in the lamina propria, extension of the subepithelial space with the epithelial layer lifting up, and dilated capillaries were found mostly in the control group. Chiu scores were 0,1 and 3 , respectively, in the sham, study and control groups $(p<0.001)$.

\section{DISCUSSION}

Ischemia and reperfusion of the small intestine provoke the rupture of the mucosal barrier, bacterial translocation and the activation of inflammatory responses, ${ }^{[1]}$ as well as hydroelectrolytic and acid-alkaline equilibrium disturbances, which are manifested in distant organs. ${ }^{[14]}$ With the return of blood perfusion, the influx of calcium into the intracellular medium increases, which leads to an expressive increase in phospholipase $A 2$ activity. Arachidonic acid released by phospholipase $\mathrm{A} 2$ is metabolized during reperfusion by the enzyme cyclooxygenase, generating prostaglandins, thromboxane and prostacyclins, and by the enzyme lipoxygenase, which generates leukotrienes. ${ }^{[15]}$ Another factor that induces intestinal injury after reperfusion is the generation of free radicals from oxygen molecules, derived from the electron transport chains of the mitochondria, xanthine-oxidase metabolism, endothelial cells, prostaglandins, and activated neutrophils. ${ }^{[4]}$ 


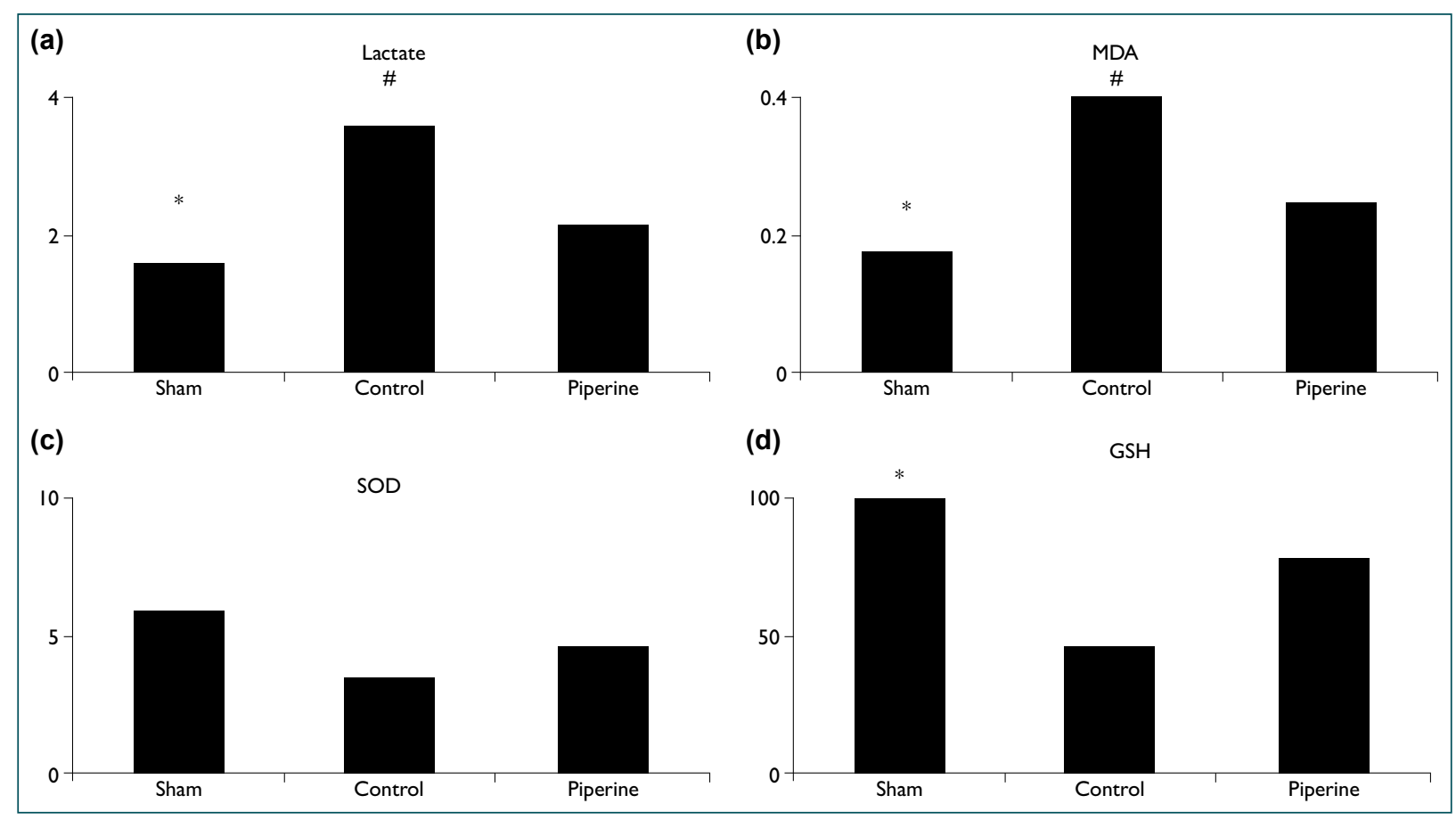

Figure 1. (a) The comparison of serum lactate levels. (b) The comparison of MDA levels. (c) The comparison of serum SOD levels. (d) The comparison of GSH levels. *: $p<0.001$ Sham group versus Control and Piperine groups; \#: $p<0.001$ Control versus Piperine group.

Many studies in the literature have evaluated a lot of materials to prevent or decrease the effects of IRI. Many radical scavengers, interestingly naturally occurring antioxidants, have been found to be effective in inhibiting the induction of lipid peroxidation and ROS. ${ }^{[16-18]}$ Studies have also indicated that various spice principles form an important group as antioxidants. ${ }^{[19-21]}$ In this study, we investigated whether piperine might have a protective role in an experimental intestinal ischemia-reperfusion model in rats. Piperine has been demonstrated in in vitro experiments to protect against oxidative damage by inhibiting or quenching free radicals and ROS and inhibiting lipid peroxidation. ${ }^{[12,22]}$ The aqueous extract of black pepper as well as piperine have been examined for their effect on human PMNL 5-lipoxygenase (5LO), the key enzyme involved in biosynthesis of leukotrienes. [23] The formation of the 5-LO product 5-HETE was significantly inhibited with $60 \mu \mathrm{M}$ piperine. Thus, piperine of black pepper might exert an antioxidant physiological role by modulating the 5-LO pathway. Using diabetes mellitus as a model of oxidative damage, Rauscher et al. ${ }^{[6]}$ investigated whether intraperitoneal piperine treatment would protect against diabetes-induced oxidative stress. They demonstrated that treatment with piperine reversed the diabetic effects on glutathione concentration in the brain, on renal GSH and SOD activities, and on cardiac glutathione reductase activity and lipid peroxidation.

Selvendiran recently investigated the impact of piperine on alterations of the mitochondrial antioxidant system and lipid peroxidation. Oral supplementation of piperine revealed a decrease in the extent of mitochondrial lipid peroxidation and concomitant increase in the activities of enzymatic antioxi- dants (SOD, catalase, GSH) and nonenzymatic antioxidants (reduced glutathione, vitamin E, vitamin C). They reported that piperine modulates lipid peroxidation and increases the antioxidant defense system. ${ }^{[24]}$

Vijayakumar et al. ${ }^{[25]}$ recently examined the effect of supplementation of black pepper or piperine on tissue lipid peroxidation and enzymic and non-enzymic antioxidants in rats fed a high-fat diet, and they observed that these spices can reduce high-fat diet-induced oxidative stress. They observed that simultaneous supplementation with black pepper or piperine lowered thiobarbituric acid reactive substances and conjugated dienes levels and maintained SOD, catalase, GSH, glutathione-S-transferase, and reduced glutathione levels near to those of control rats.

In this study, the results were consistent with the previous reports. The statistically significant highest MDA and lactate levels and the statistically significant lowest GSH and SOD levels were in the control group. MDA and lactate levels of the piperine group were significantly lower than in the control group, and GSH and SOD levels were significantly higher. These results clearly show that intraperitoneal administration of piperine significantly decreases the effects of lipid peroxidation and protects against oxidative damage. The histopathologic examination revealed similar findings with intact intestinal wall in the sham group and well-preserved, mildly affected structures in the study group, but with disruption of villous pattern and lamina propria with dilated capillaries and increased cellularity in the control group. Although there are numerous reports 
about the effectivity of spice species on peroxidation and oxidative stress, since IRI is a very complex process including many yet to be resolved steps in its pathogenesis, new studies are warranted for a further understanding of the biological effects of piperine regarding its inhibitory activities in IRI.

In conclusion, in this experimental IRI model in rats, piperine treatment decreased IRI of the small intestine according to both morphological and biochemical criteria, even though its detailed mechanism of action remains unclear.

\section{Conflict of interest: None declared.}

\section{REFERENCES}

1. Cerqueira NF, Hussni CA, Yoshida WB. Pathophysiology of mesenteric ischemia/reperfusion: a review. Acta Cir Bras 2005;20:336-43.

2. Granger DN, Höllwarth ME, Parks DA. Ischemia-reperfusion injury: role of oxygen-derived free radicals. Acta Physiol Scand Suppl 1986;548:47-63.

3. McCord JM. Oxygen-derived free radicals in postischemic tissue injury. N Engl J Med 1985;312:159-63.

4. Grace PA. Ischaemia-reperfusion injury. Br J Surg 1994;81:637-47.

5. Srinivasan K. Black pepper and its pungent principle-piperine: a review of diverse physiological effects. Crit Rev Food Sci Nutr 2007;47:73548.

6. Rauscher FM, Sanders RA, Watkins JB 3rd. Effects of piperine on antioxidant pathways in tissues from normal and streptozotocin-induced diabetic rats. J Biochem Mol Toxicol 2000;14:329-34.

7. Bano G, Raina RK, Zutshi U, Bedi KL, Johri RK, Sharma SC. Effect of piperine on bioavailability and pharmacokinetics of propranolol and theophylline in healthy volunteers. Eur J Clin Pharmacol 1991;41:6157.

8. Atal CK, Dubey RK, Singh J. Biochemical basis of enhanced drug bioavailability by piperine: evidence that piperine is a potent inhibitor of drug metabolism. J Pharmacol Exp Ther 1985;232:258-62.

9. Dalvi RR, Dalvi PS. Differences in the effects of piperine and piperonyl butoxide on hepatic drug-metabolizing enzyme system in rats. Drug Chem Toxicol 1991;14:219-29.

10. Dhuley JN, Raman PH, Mujumdar AM, Naik SR. Inhibition of lipid peroxidation by piperine during experimental inflammation in rats. Indian J Exp Biol 1993;31:443-5.

11. Khajuria A, Thusu N, Zutshi U, Bedi KL. Piperine modulation of carcinogen induced oxidative stress in intestinal mucosa. Mol Cell Biochem 1998;189:113-8.

12. Mittal R, Gupta RL. In vitro antioxidant activity of piperine. Methods Find Exp Clin Pharmacol 2000;22:271-4.

13. Hei ZQ, Gan XL, Luo GJ, Li SR, Cai J. Pretreatment of cromolyn sodium prior to reperfusion attenuates early reperfusion injury after the small intestine ischemia in rats. World J Gastroenterol 2007;13:513946.

14. Turnage RH, Guice KS, Oldham KT. Endotoxemia and remote organ injury following intestinal reperfusion. J Surg Res 1994;56:571-8.

15. Cuzzocrea S, Rossi A, Serraino I, Di Paola R, Dugo L, Genovese T, et al. 5-lipoxygenase knockout mice exhibit a resistance to splanchnic artery occlusion shock. Shock 2003;20:230-6.

16. Kazez A, Demirbağ M, Ustündağ B, Ozercan IH, Sağlam M. The role of melatonin in prevention of intestinal ischemia-reperfusion injury in rats. J Pediatr Surg 2000;35:1444-8.

17. Augustin AJ, Goldstein RK, Milz J, Lutz J. Influence of anti-inflammatory drugs and free radical scavengers on intestinal ischemia induced oxidative tissue damage. Adv Exp Med Biol 1992;316:239-51.

18. Erdogan H, Fadillioglu E, Yagmurca M, Uçar M, Irmak MK. Protein oxidation and lipid peroxidation after renal ischemia-reperfusion injury: protective effects of erdosteine and $\mathrm{N}$-acetylcysteine. Urol Res 2006;34:41-6.

19. Shen SQ, Zhang Y, Xiang JJ, Xiong CL. Protective effect of curcumin against liver warm ischemia/reperfusion injury in rat model is associated with regulation of heat shock protein and antioxidant enzymes. World J Gastroenterol 2007;13:1953-61.

20. Murugan P, Pari L. Antioxidant effect of tetrahydrocurcumin in streptozotocin-nicotinamide induced diabetic rats. Life Sci 2006;79:1720-8.

21. Jiang H, Deng CS, Zhang M, Xia J. Curcumin-attenuated trinitrobenzene sulphonic acid induces chronic colitis by inhibiting expression of cyclooxygenase-2. World J Gastroenterol 2006;12:3848-53.

22. Naidu KA, Thippeswamy NB. Inhibition of human low density lipoprotein oxidation by active principles from spices. Mol Cell Biochem 2002;229:19-23.

23. Prasad NS, Raghavendra R, Lokesh BR, Naidu KA. Spice phenolics inhibit human PMNL 5-lipoxygenase. Prostaglandins Leukot Essent Fatty Acids 2004;70:521-8.

24. Selvendiran K, Senthilnathan P, Magesh V, Sakthisekaran D. Modulatory effect of Piperine on mitochondrial antioxidant system in Benzo(a) pyrene-induced experimental lung carcinogenesis. Phytomedicine 2004;11:85-9.

25. Vijayakumar RS, Surya D, Nalini N. Antioxidant efficacy of black pepper (Piper nigrum L.) and piperine in rats with high fat diet induced oxidative stress. Redox Rep 2004;9:105-10.

\section{DENEYSEL ÇALIŞMA - ÖZET}

\section{Sıçanlarda oluşturulan deneysel iskemi-reperfüzyon modelinde piperinin etkileri Dr. Hızır Yakup Akyıldız, Dr. Adem Karabacak, Dr. Muhammet Akyüz, Dr. Erdoğan Sözüer, Dr. Alper Akcan}

Erciyes Üniversitesi Tıp Fakültesi, Genel Cerrahi Anabilim Dalı, Kayseri

AMAÇ: Piperin oksidatif hasara ve lipit peroksidasyonuna karşı koruyucu etkisi bildirilmiş bir baharat türevidir. Çalışmamızda ince bağırsak iskemireperfüzyon hasarını önlenmesinde piperinin etkisini incelemeyi amaçladık.

GEREÇ VE YÖNTEM: Sıçanlar her biri 8 sıçan içeren 3 gruba ayrıldı. Sham grubundaki sıçanlara sadece laparotomi ve gözlem uygulandı. Kontrol ve çalışma grubundaki hayvanlara 45 dakikalık iskemiyi takiben 60 dakikalık reperfüzyon uygulandı. Çalışma grubuna piperin, reperfüzyon işleminden hemen önce $10 \mathrm{mg} / \mathrm{kg}$ dozunda periton içi yolla verildi. Laktat seviyelerinin ölçümü için kan numuneleri alındı. Histopatolojik inceleme, doku malondialdehid, süperoksit dismutaz ve glütatyon aktivitesi ölçümleri için de terminal ileum rezeksiyonu gerçekleştirildi. Gruplar arası istatistiki karşılaştırma ANOVA testi ile yapıldı. 
BULGULAR: Kontrol grubunda laktat ve malondialdehid seviyeleri çalışma ve sham gruplarına göre anlamlı olarak yüksekti $(p<0.00 \mathrm{I})$. Çalışma grubunda, süperoksit dismütaz ve glutatyon aktiviteleri kontrol grubundan anlamlı olarak yüksekti $(p<0.001)$. Sham grubu her iki parametrede de en fazla aktiviteye sahipti. Histopatolojik incelemede kontrol grubunda villöz yapının ve lamina propria bütünlüğüün bozulduğu görüldü. TARTIŞMA: Reperfüzyondan hemen önce periton içi verilen $10 \mathrm{mg} / \mathrm{kg}$ piperin ince bağırsaklarda iskemi-reperfüzyon hasarını azaltabilir. Anahtar sözcükler: İskemi, piperin, reperfüzyon, ince bağırsak.

Ulus Travma Acil Cerr Derg 2013;19(5):387-391 doi: 10.5505/tjtes.20।3.48457 